\title{
Van Galen's memorandum on the Alor Islands in 1946. An annotated translation with an introduction. Part 1.
}

\section{Av Hans Hägerdal}

Among the 17,000 islands of Indonesia, the Alor Islands are among the lesser known, but far from the least interesting. For the modern tourist they are primarily known as an excellent diving resort, that attracts a modest but devoted group of Westerners each year. For art historians their fame rests on the moko, the hourglass-shaped bronze drums that were once found all over the islands. Students of anthropology may know Alor via the well-known monograph of Cora Du Bois, The People of Alor (1944). Linguists find the plethora of local languages, at least fifteen in number, intriguing, the more so since speakers of Austronesian and Papuan languages meet here. And avid readers of tropical travel literature may have encountered the islands as the supposed abode of ferocious cannibals and headhunters.

To put it briefly, the Alor Islands are situated in the Nusa Tenggara Timur province of eastern Indonesia, north of Timor and east of Flores and the Solor Islands. They consist of two larger islands, Alor and Pantar, and some smaller ones. The mountainous islands cover an area which is about half of Bali's, with a mixed population of Christians and Muslims. As is the case with much of Indonesia's history outside Java, the past of this little archipelago is fragmentarily known up to the nineteenth century. Knowledge of the written word was utterly limited until modern times, and scholars have to piece Alorese history together from indigenous oral tradition, accounts by foreigners, and linguistic and archaeological data.

A stage in the process of exploring the dynamics of this society is to ensure that interesting texts are made available for the general public. The Dutch colonials, dominant in parts of Indonesia since the early seventeenth century, had loosely counted the Alor Islands to their sphere of interest since 1613 . However, they were only able to implement a colonial rule in the stricter sense from the early twentieth century. The colonial government was therefore in place for no more than about three or four decades, being interrupted by the Japanese occupation in 1942-45 and the ensuing Indonesian Revolusi. In December 1949 the islands were incorporated in the new Indonesian nation. ${ }^{1}$ During their brief colonial tenure, the Dutch governmental officials (bestuursambtenaren) wrote reports about the rather unprofitable islands they were set to rule. The Dutch East Indian possessions were divided in various residencies, of which one was Timor en Onderhoorigheden (Timor and Dependencies). It consisted of West Timor, Rote, Savu, the Solor and Alor Islands, Flores, Sumba and Sumbawa, and was headed by a Resident seated in the Timorese port town Kupang. ${ }^{2}$ Under the Resident were various Controleurs (Controllers), one of whom was in charge of the Alor Islands. When a Resident or Con-

1 Ricklefs 1981, p. 220.

2 Gonggrijp 1934, pp. 19, 137. 
troleur ended his term, he was expected to write a survey of the area, a Memorie van Overgave (Memorandum of Succession). To the best of my knowledge, the only general Memorie that has survived from the Alor Islands is the one that is translated and commented below. It has been preserved in a comprehensive collection of writings of governmental officials, Collectie Losse Aanwinsten Bestuursambtenaren, found in the Nationaal Archief in The Hague. The author, G.A.M. van Galen, succeeded the Controleur K. Reijnders in 1938, but his term was interrupted by the rule of Japan in 1942-45. ${ }^{3}$ He drew up the text at the end of his second term in 1946, at a time when the Dutch had just come back to Indonesia after the Japanese capitulation. While the nationalist Revolusi evolved in Java, Sumatra and Sulawesi, large parts of eastern Indonesia including the Alor Islands were incorporated into a quasi-state called Negara Indonesia Timoer (The State of East Indonesia) under Dutch auspices. ${ }^{4}$ Although there was nationalist agitation on Timor and surrounding islands, there was no actual fighting between anti- and pro-Dutch forces. The "state" was nevertheless dissolved following the round-table discussions that led to the Dutch recognition of the Indonesian Republic in 1949.

The Memories van Overgave of the Dutch East Indies are often very good historical sources. The European officials routinely knew Malay (later to be developed into Indonesian) and had received a thorough training back in the Netherlands. The more ambitious officials collected data on indigenous customs ( $a d a t$ ) and traditions, often delving into local history even before the Dutch takeover. Van Galen fortunately belongs to the latter type. He undertakes comprehensive surveys of the traditional raja-ships that dotted Alor and Pantar, of geographical features, religious conditions, customs, and various social, economic, and political issues. All this is amply complemented with genealogies, maps and statistical tables. He evidently takes much of the material from the reports of his predecessors, reports which are now to all appearances lost.

Van Galen does not say a lot about the history of the islands before the appearance of the Dutch, perhaps because the sources for such a history were so fragmentary and inaccessible. A brief background may therefore serve to set his account in context. In scattered sources from the fourteenth century onwards, the geographical term Galiyao is found. Originally this would seem to have been a term for Pantar Island in one of the local languages. But Galiyao also denoted a bond of five coastal domains situated on Pantar and western Alor: Pandai, Blagar, Barnusa, Alor (Proper) and Kui. The bond had Pandai in northern Pantar as its head, but it never developed into something akin to a kingdom. The Galiyao league, in turn, had a loose political connection with the Solor Islands to the west. Like the Solorese, the coastal dwellers of Galiyao were influenced by Islam which became dominant in northern Sumatra, Java and the Moluccas in the fifteenth and sixteenth centuries. Some of the Islamic influence seems to have reached Alor and Pantar from the Ternate Sultanate in the Moluccas - one of the smaller islands in the group is actually called Ternate. ${ }^{5}$

3 Bell 2009, p. 99.

4 Ricklefs 1981, p. 212.

5 A full discussion of the complicated nomenclature is found in Hägerdal 2010, pp. 220-23. 
Another name found in sixteenth and seventeenth-century travel accounts is Malua, which is the island that we now call Alor. Alor was originally a raja-ship in the north-western part of Alor Island. The chiefs of that place entertained some commercial and other contacts with the wider world, which gave it a degree of prominence in foreign eyes. Alor could therefore be used for the entire island, or even for the entire group. A third name often used for the eastern main island is Ombai. This geographical confusion indicates that regions rather than islands were important as units from the local perspective. While Alor and Kui in the west of Alor Island were members of Galiyao, the eastern parts went their own ways. Some places along the coast evolved as princedoms at the time: Mataru, Batulolong, Pureman, Kolana. ${ }^{6}$ The inhabitants of the mountainous interior had a frightful reputation for being cannibals. The rumour is repeated intermittently in travel accounts from the sixteenth to the nineteenth century, but it is not clearly documented. ${ }^{7}$ The threatening or hostile reception that was sometimes accorded foreign travellers can also be explained through fear - the basically stateless Alor Islands were sometimes the subjects of raiding, and were a source of slaves for other parts of Indonesia. ${ }^{8}$

The Portuguese arrived in Indonesia in 1511-12 and the Dutch in 1596. The first detailed account of the Alorese is, however, written by the Italian Antonio Pigafetta who acompanied the Magellan expedition in 1519-22. He described the inhabitants of "Mallua" as "wild and beastly" and "the ugliest people in this part of India," and alleged them to be cannibals on a grand scale. Pigafetta characterized them as stateless people who obeyed no kings and were thus opposed to European standards of normality. They used bows and arrows and protected themselves with a cuirass of buffalo hide. Their dress otherwise consisted of a loincloth made of bark (in Malay, cawat). In spite of the threatening postures of the inhabitants when the Spaniards came ashore, the Alorese quickly became friends with the whites after they received some gifts. ${ }^{9}$ The ethnographical details provided by Pigafetta mostly accord with later scholarly studies of Alorese society, although these studies do not endorse the portrayal of the inhabitants as ferocious eaters of human flesh. ${ }^{10}$

Portugal and the Netherlands fought a bitter struggle in Asian waters for the better part of the seventeenth century. Portuguese merchants had been visiting Solor since at least the $1550 \mathrm{~s}$, and they no doubt had some knowledge of the nearby Alor Islands. In 1613 the Portuguese fort on Solor was conquered by an armada of the Dutch East India Company (VOC), and the Portuguese moved their base to Larantuka on Flores. ${ }^{11}$ Later on, in the 1650 s, they established a permanent base on Timor where they would hang on until 1975. The Galiyao league immediately declared for the Company, presumably a consequence of their old connections with the So-

6 Certain other places on Alor Island were occasionally known as domains or princedoms in the nineteenth century: Mademang, Paitoko, Beno, Hamapu, Kelong, Ika Raka (or Mia Raka), Delluntuw (Francis, H 548, KITLV Archive; Van Lijnden 1851).

7 Arago 1823, p. 210; Arago 1844, pp. 30-7.

8 LeRoux 1929, p. 24.

9 LeRoux 1929, p. 18.

$10 \mathrm{Du}$ Bois 1944, p. 170, basing her on interviews with locals from highland Alor, asserts that cannibalism was a frightening and abhorring idea among the Alorese, one that was associated with witchcraft.

11 De Roever 2002, pp. 105-31; Boxer 1947. 


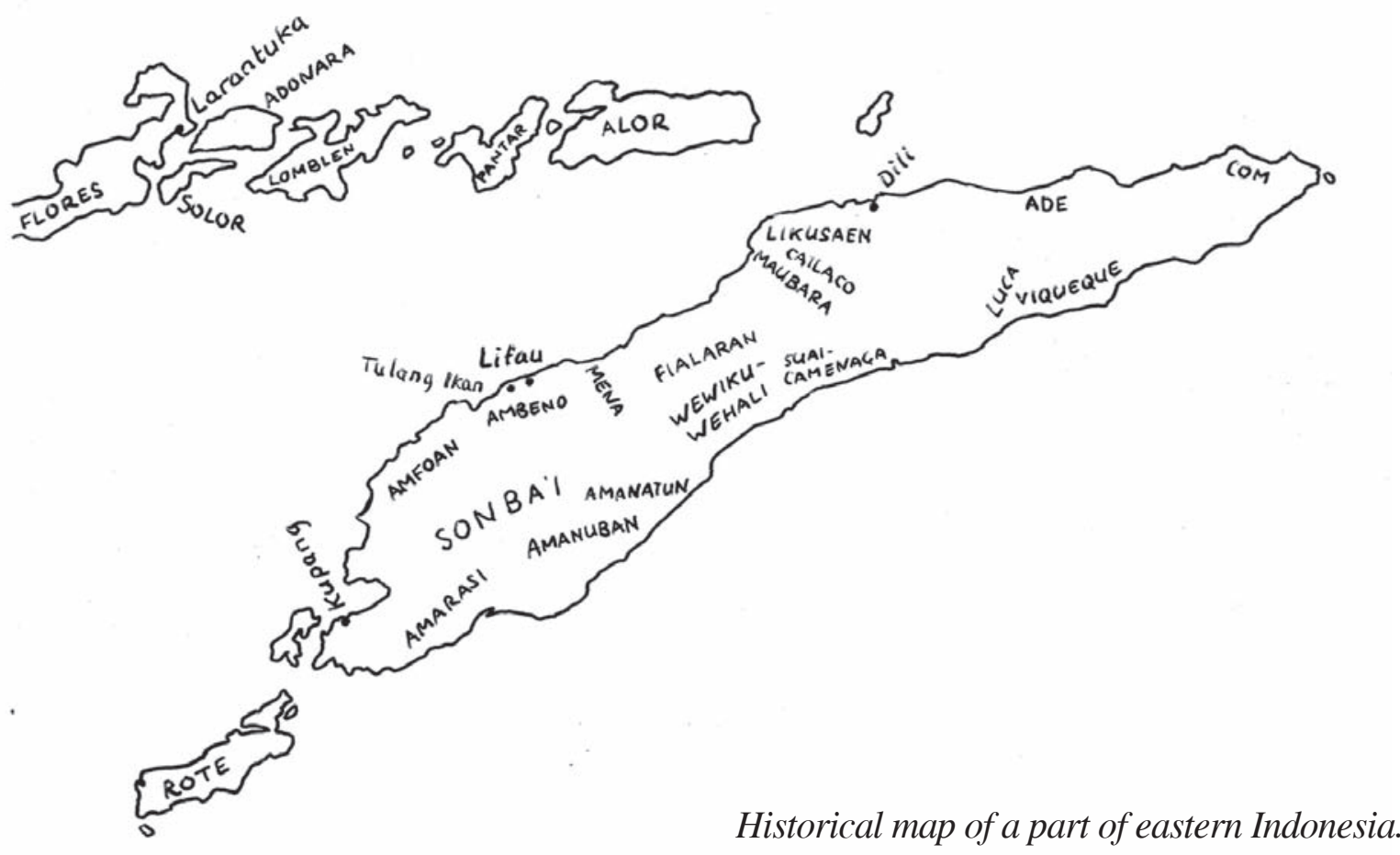

lorese princedoms. For the next sixty years, however, the Dutch had almost no interaction with the Alor Islands. For part of this time the seafaring Makassarese people from Sulawesi enjoyed a vague overlordship and demanded a light tribute from the Alorese. ${ }^{12}$ It was only in the $1670 \mathrm{~s}$, when they had been based in Kupang in West Timor for a long time, that the Company began to explore possibilities of trade in these quarters. These possibilities were found to be limited: only some beeswax and slaves could be obtained from the local rajas. But there were also other flows of trade outside the VOC orbit. The Portuguese in East Flores and Timor sold iron pieces, cutlasses and axes to the mountaineers, since the Alorese did not produce metalwork themselves. Traders from Sulawesi brought gongs and apparently also moko drums, which (at least by the late colonial period) were made in workshops in Java. ${ }^{13}$ Gongs and moko were essential as bridewealth in the local marriage system. Merchants and adventurers from Sulawesi visited the eastern parts of Indonesia and maintained their own network outside the system of monopolies that the VOC tried to maintain. ${ }^{14}$ In the Alor Islands, which were relatively low-technological and lacked bonafide states, these sea migrants could gain influence.

During part of the eighteenth century trading was rather lively between merchants of Kupang and Alor, and on one occasion in 1719 the Dutch took resolute action to block the Portuguese from maintaining a fort there. ${ }^{15}$ Towards the end of the century, however, the capabilities of the VOC were on the wane, and the Kupang authorities admitted that they had no influence whatsoever in these quarters. This was sealed by the troubles besetting the Dutch East Indies during the French Revolutionary and Napoleon Wars. Kupang was occupied by the British in 1812, and in the next year the rajas of Pandai and Alor Proper asked to be accepted under Portuguese

12 Hägerdal 2010, pp. 230-31.

13 The source material for the seventeenth century is summarized in Hägerdal 2010, pp. 223-30.

14 Andaya 1995.

15 Coolhas 1979, p. 357. 
authority. The Portuguese governor in Dili in East Timor endorsed this and sent flags to confirm the new suzerainty. ${ }^{16}$ After the fall of Napoleon the British ceded their recent conquests in the East Indies in 1816, and the returning Dutch claimed back the Portuguese gains. In fact the Alor Islands appear to have continued as a sort of diplomatic no man's land, claimed by the two colonial powers but being of too little significance to evoke a serious dispute. ${ }^{17}$

There had hitherto been a loose association between the five Galiyao domains and the five Solorese domains under Dutch suzerainty. ${ }^{18}$ This was known as Sepulu Pantai, the Ten Shores. But in 1820 the association broke up due to internal conflicts, the details of which are not known. The Dutch had long kept a representative, a Posthouder, in Lohayong on Solor, who was also responsible for keeping an eye on the Alor Islands - however little that may have meant in practice. Probably concerned about the recent Portuguese advances, the Dutch authorities in Kupang placed a particular Posthouder on Pantar from 1820 to 1831. Again, this was hardly tantamount to "colonial" governance, but more a way to mark the presence of the Netherlands. In 1831 the post on the Alor Islands was abandoned through the decision of a commissioner from Batavia. ${ }^{19}$

However, events in the next decade made the Dutch wary about the position of the Alor Islands. Some of the local rajas were keeping Portuguese flags and considered the Governor in Dili to be their ultimate protector. In particular the pro-Portuguese princedoms Oecussi and Liquiçá on Timor's north coast enjoyed influence on Alor. Added to this were the perennial conflicts that raged between the coastal, partly Muslim, population, and the animist mountain peoples. In 1846 the three coastal rajas of Kui, Blagar, and Beno got tired of the aggression from the mountain dwellers and asked Oecussi for help. At the same time two other rajas, of Alor Proper and Barnusa, called for assistance from Amfoan for the same purpose. Amfoan was also a Timorese princedom but it belonged to the Dutch sphere of power. The detachments from Oecussi and Amfoan encountered each other on Alor. The former took fright and sailed back to Timor, while the warriors of Amfoan proceeded to wage war on the mountain people. ${ }^{20}$

The Dutch authorities in Kupang and Batavia felt worried about the intervention of Portuguese Timorese soldiers. The matter was part of a broader concern to delineate the colonial borders that was increasingly felt during the nineteenth century. Negotiations with the Portuguese Governor in Dili led to an agreement in 1851. The Governor handed over the pro-Portuguese areas in East Flores, Solor, Adonara, Lembata, Pantar and Alor to the Dutch East India Government in return for a sum of money. At the same time the border between Dutch and Portuguese Timor was fixed, although some questions remained. ${ }^{21}$ The opinion of the locals was not heard in the matter, and the border agreement met with bitterness among some local elites. On Alor it was in particular Kui, a princedom in the south-west of the island that refused to hoist the Dutch tricolor. In January 1855 the Dutch steamship Vesuvius appeared in the roadstead of Kui and re16 ANRI Timor: 37; Kontrak Perjanjian 2007, p. 316.

17 In a Portuguese geographical dictionary of 1850, Allor grande and Allor pequeno (Alor Besar and Alor Kecil, or possibly denoting Alor and Pantar) are still emumerated as parts of the Portuguese realm (Monteiro 1850, p. 413).

18 Barnes 1995, p. 499.

19 ANRI Timor: 57.

20 ANRI Timor: 57.

21 Pélissier 1996, pp. 33-6. 
duced the village to rubble with its guns. Raja Gesi was deposed and replaced with an obedient younger relative. ${ }^{22}$ Nevertheless, the Dutch were still not able to impose their Pax Neerlandica on the islands. In the same year some mountain people of the domain Barnusa on Pantar came down to the central village at the coast which they attacked and ruined completely. As a result the raja had to flee to Alor Proper to save himself. ${ }^{23}$ Violent internal incidents are known in the following decades, and the Dutch did not take a very active stance to stop it. Their concern was to keep Portuguese influence out but not to interfere in the local societies in the Timor area. Even within their limited aims they were not always successful. When the Dutch sovereign status over the Alor Islands was confirmed in 1860 the responsible officials quite simply neglected to collect the Portuguese flags that some coastal rajas possessed, or to give them Dutch tricolors instead. ${ }^{24}$ As late as in c. 1880 the Raja of Kui sent tributes consisting of beeswax to Oecussi in Portuguese Timor in the hope of obtaining assistance to fight the mountain Alorese. Captured mountaineers were sent from Kui and Kolana to Liquiçá as slaves, many decades after the official abolition of slave trade in the Dutch possessions. ${ }^{25}$

Actual Dutch rule was only achieved in the early twentieth century. Batavia at last abandoned its old policy of non-intervention in the outer regions of its East Indian empire. ${ }^{26}$ The new, increasingly active way of managing their colonies was coupled with a so-called "ethical" policy. The colonies were ideally not to be treated just as milkcows from which as much produce as possible was squeezed. The Dutch colonial establishment also felt that non-intervention was harmful for stability and prosperity, and that a good and ordered government must be implemented to bring the fruits of civilization to the islands of the "emerald girdle." After the end of the extended Aceh War in about 1903, a large number of expeditions and interventions were launched across the archipelago that finally imposed a colonial rule in the commonly understood sense: Timor 1905-10, South Sulawesi 1905, Bali 1906-08, and so on. The ethical aspects of the matter were soon lost from sight since the colonial actions cost much Indonesian blood. ${ }^{27}$ As appears from the Memorie of Van Galen, a number of contracts and declarations were signed by local rajas on Alor and Pantar in the last years of the nineteenth and the first years of the twentieth centuries. In a general sense, colonial governance was implemented in 1910-12. No major military expedition was needed to pacify the small and poorly armed polities, but from time to time resistance flared up against taxation and corvée service. When independence was eventually achieved in 1949, the pre-colonial time was therefore still in living memory among many Alorese.

We must remember that the text was intended for official use rather than for a broader audience. However, among all the names and dates, an interesting image emerges of the workings of colonialism. The heavy-handed way of dealing with all kind of protests is illustrated by the numerous incidents that took place in the first half of the nineteenth century. Likewise, the Dutch ways of mastering the various local princedoms, and putting them in a neat bureaucra-

22 ANRI Timor: 118.

23 ANRI Timor: 119.

24 Ecoma Verstege 1878, Nationaal Archief, The Hague.

25 Mailrapport 1880: 333, Nationaal Archief, The Hague.

26 Gonggrijp 1934, p. 428.

27 Ricklefs 1981, pp. 138, 143-4. 


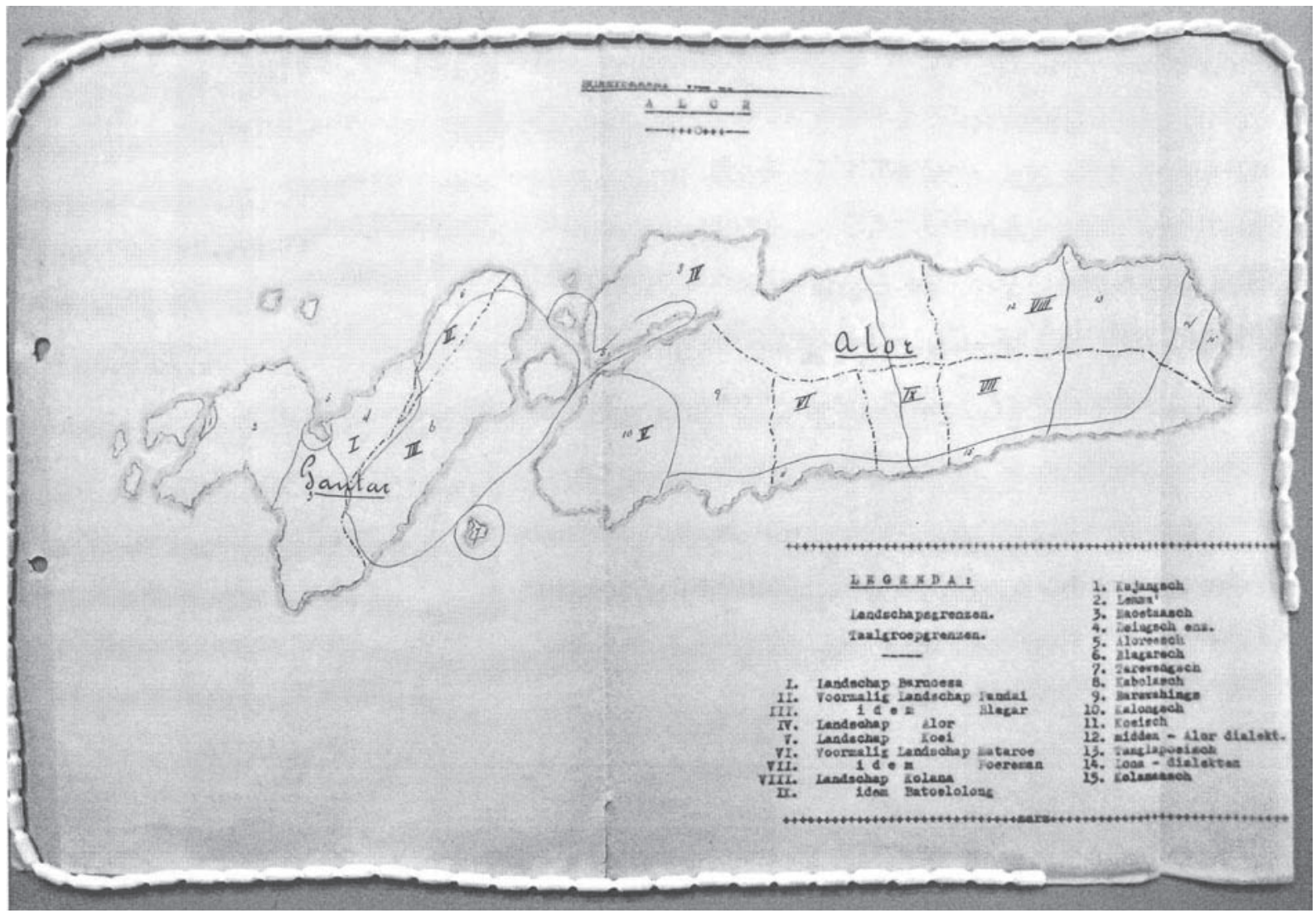

Map of Alor and Pantar.

tized fold, is highlighted. So is the zealous propagation of Christianity to the detriment of old belief systems, with the stated aim to strengthen the bonds between the indigenous people and the colonials.

The translation below encompasses pages 1-35 of Van Galen's manuscript of 74 pages plus appendixes. It covers history, geography, and part of a section on population. The spelling of names has been modified in order to conform to modern Indonesian practice and avoid unnecessary confusion. Thus the Dutch combination "oe" has been replaced with "u", "tj" with "c", and "dj" with " $j$ ". Otherwise my ambition has been to provide a translation that is as faithful to the original as possible. ${ }^{28}$ The second part of the manuscript will be published in a forthcoming issue.

28 I wish to express my gratitude to Dr. Per Sivefors, School of Language and Literature, Linnaeus University, for commenting on an early draft of the translation. 


\title{
Memorie van Overgave van den fundgeerend Controleur van Alor G.A.M. van Galen
}

\author{
Dated 15 December 1946. \\ Collectie Losse Aanwinsten Bestuursambtenaren No. 26, \\ Nationaal Archief, Den Haag
}

\section{HISTORY}

The area of the Onderafdeeling ${ }^{29}$ Alor, most recently organizationally defined by State Paper 1929 No. 196, previously stood under partly Portuguese suzerainty; however, since August 6, 1851 it came entirely under Dutch rule (P.J. Veth, Aardrijkkundig en Statisch Woordenboek van Nederlandsch-Indië II, 1869, p. 599). ${ }^{30}$

By then the Portuguese effort had not gone further than the bestowing of Portuguese flags on some coastal chiefs, such as those of Kui, Mataru, Batulolong, Kolana and Blagar.

Also our ruling effort did initially not go much further, since when the Government sought a loose association with Alor, it was limited to the acknowledgement of coastal chiefs as rajas and the placement of a posthouder in Alor Kecil, situated at the entrance to the Kabola Bay (around 1861).

These chiefs of coastal settlements, whose population was often descended from somewhere else and which did not accord with the autochtonous mountain people in terms of language or religion, nor in $a d a t,{ }^{31}$ were all too happy to be established as rajas of the inland beyond their territory, although their power there was in practice nil, and they seldom or even never went there. And on the other hand, the mountaineers did not acknowledge the coastal chiefs as their "prince;" thus the posthouder Morgenstern still wrote in the year 1909, in his missive of July 31, 1909 No. 103, that the mountain chiefs considered the rajas and Kapitans ${ }^{32}$ as middlemen in the barter trade, and as interpreters when the European Government had to come into contact with them.

When it was decided in the period of the Governor-General Van Heutz to bring the socalled outer possessions more thoroughly under our rule, it seemed necessary to confirm

\footnotetext{
29 Sub-division.

30 The agreement with the Portuguese governor Lopes de Lima, signed in 1851, was not endorsed by the home government of Portugal, and had to be renegotiated. The two colonial powers came to a new agreement, in fact identical with the former one, in 1854. The resulting Treaty of Lisbon was eventually signed on April 20, 1859. Some details concerning the colonial borderline on Timor were not settled until 1916 (Pélissier 1996, pp. 33-40).

31 Adat is the traditional body of customs and regulations of the various Indonesian societies. The term was important in the policy of the Dutch East India Government. Researchers and officials tried to codify the various regional or local adat with varying success (Gonggrijp 1934, pp. 1223-26).

32 Kapitan is a title derived from Portuguese capitão, captain. In many eastern Indonesian societies it is used for the assistant of a raja or a district ruler.
} 
the power of the coastal chiefs over the mountaineers by the force of arms. ${ }^{33}$ Here follows a survey of the patrol activity.

On July 31, 1910 three groups of marechaussee ${ }^{34}$ from Kupang were at Alor Kecil under the command of Lieutenant Adelberg.

Alor-Kecil was the seat of the posthouder Meulemans ${ }^{35}$ who had some prajurits ${ }^{36}$ (armed policemen) at his disposal.

This exploration detachment patrolled on Alor during 1910-1911 and then returned to Kupang. ${ }^{37}$ The relations with the mountain people were in general friendly. They had respect for our well-armed troops. Only once was a camp attacked (August 21, 1910) in the Lawui complex (Kewaai district, Limbur). This was supposedly perpetrated by the inhabitants of Afenlaga and Afenbeka. They were repelled with substantial losses (14 killed).

After the withdrawal of the exploration detachment it soon appeared that the prajurits which were available to the official were still not enough for a true exercise of power.

A steady garrison of militaries was placed at Kalabahi (where the governance had been moved) and civil rule was given over to the military commander.

In 1913 military action was necessary on the island Pantar where the mountaineers were at war with the coastal settlement Blangmerang. Here the mountain people were, contrary to the population of Alor, in the possession of shotguns imported via the Solor Islands, especially by the kampung ${ }^{38}$ Lamahala on Adonara and by traders from Makasar. ${ }^{39}$ There were 7 casualties on our side, including a doctor, a sergeant and five men, whose graves are still in Blangmerang.

In the beginning of 1914 the population of Atimelang (kapitan-ship Limbur) were rumoured to plan a rebellion, while in the kapitan-ship Probur (Kalong, landschap ${ }^{40} \mathrm{Kui}$ ) military patrols were also necessary.

In 1915 the Kapitan of Mademang was murdered by the population of the Maupui complex (landschap Pureman) as a revenge for oppression exerted on them. Previously they had already refused to work on the roads, as well as pay taxes. Shortly after the occurred, the officer-patrol-commander Lieutenant du Croo was in place with a brigade. Although he tried

33 Correctly spelt Van Heutsz (1851-1924). He was the Governor-General of Netherlands East India in 1904-09. Known as a hawkish type, he was responsible for several armed interventions in hitherto virtually autonomous areas (Gonggrijp 1934, p. 428).

34 Military police.

35 Meulemans was the first regular Controleur in 1905-10 (Bell 2009, p. 99).

36 Prajurit is a Javanese word for warrior, used in this context as an indigenous auxiliary corps, established in the East Indies in 1843. They were originally reinforcements for the army, but later served to maintain peace and order in various parts of the archipelago (Gonggrijp 1934, p. 730).

37 Kupang, today the capital of the Nusa Tenggara Timur province, was the seat of the Resident of Timor en Onderhoorigheden (Timor and Dependencies).

38 A kampung (kampong) is a minor settlement. Depending on the context it can be a quarter, hamlet or village (Gonggrijp 1934, p. 616). In this case it has the last meaning.

39 Makassar (Makasar) is traditionally the most important city of South Sulawesi. Makassarese traders and sailors were important in the eastern parts of Indonesia for centuries, sometimes bringing goods without Dutch approval or knowledge.

40 Landschap, in this context a term denoting a territory, especially one governed by a raja (zelfbesturend landschap, self-ruling territory). 
to make headway by peaceful means, the kapala ${ }^{41}$ Langsalimau and his circa 100 followers refused to submit, and so he challenged the company, incited by the orang tua ${ }^{42}$ and the... women. Through a few attacks in the night the actual resistance was rapidly broken; and after 40 rebels had fallen, including some main perpetrators, the last rebels were captured by itinerant patrols. In July the resistance was terminated.

In August a more serious rebellion broke out in the landschap Kui. Possibly oppression was committed here too. The main reason was nevertheless unwillingness to commit corvée labour and paying taxes.

In the night of August 4-5 the seat of the Raja of Kui, Lerabaing, was attacked by a band of 150 men from the warlike and hardly reachable Kamelelang complex, and mostly burnt down. Nine persons from Lerabaing were killed and a number were injured. The Chinese toko $\mathrm{o}^{43}$ and the house of the raja were committed to the flames. The rebels lost six dead and were beaten back through the brave stance of fettor ${ }^{44}$ Sanga. A few days later a patrol was sent thither, while a brigade was sent from Kupang as reinforcement. In the ensuing fight 30 rebels fell. In October the rebellion was terminated, also thanks to the good participation of the Raja of Kui. The population moved from the lofty mountainous locations to places which could be more easily reached.

In January resistance arose on the Kabola peninsula through the incitement of the pretender of the raja family of Alor-Besar, Lawono, against the newly appointed Raja of Alor, Bala Nampira of Dulolong.

An attempt was made to set the house where the raja stayed on fire. The resistance could be subdued without spilling any blood, and Lawono and some other rebels were sentenced. In April 1916 followed a second and much more serious attempt at the instigation of persons of the raja family of Alor Besar, led by a certain Bura. A number of dissatisfied mountain kampungs (Oa, Nihing, Ananibang - present-day temukung-ship ${ }^{45}$ of Oa) were incited and in the night of March 25-26 the house of Kapitan Belang at Kalabahi was put on fire, the Kapitan was wounded, and four of his retainers were murdered. The aim was also to put the house of the raja on fire and liberate Lawono. Since militaries could actually be sent in, this was prevented. The action against the rebels was forcefully carried out, whereby 68 persons, including the main leaders, fell. The others were captured. Bura was sentenced to 10 years of prison.

Meanwhile, in April a number of perang-minded ${ }^{46}$ people tried to incite the kampungs Kanaipea, Fuimea-Tidol and Songmelang to ravage the kampung Welai and murder the kapala

41 Kapala or kepala means head, headman, chief.

42 Elder people.

43 Toko means shop. The Chinese immigrants, mostly of Minnan (Fujian) origins, were often active as traders and artisans in various Indonesian societies. They usually, but not always, stuck closely to the Dutch colonial system to further their business. Their enormous influence on the Indonesian economy is an issue to this day.

44 Fettor, from Portuguese feitor, overseer. A fettor was, in eastern Indonesia, a regent assisting the raja, or sometimes the ruler of a district of a princedom, a kefetoran.

45 Temukung is a local chief. The word is derived from the Malay-Javanese title tumenggung, which denoted the minister of a prince.

46 Perang means war in Malay. 
besar ${ }^{47}$ of Maibeka, out of dissatisfaction with the demands of corvee service and taxation. The governance was, however, warned early on. Two rebels fell, the others were captured.

In May there arose some resistance on Pantar, and this had hardly been terminated when a more serious resistance broke out in the still not much visited Kamengmi area (landschap Kolana, kapitan-ship Taramana). That was the consequence of the dissatisfaction caused by the oppression by Kapitan Jonas and the demands for corvée service and taxation. Plans were made to tempt the 20 soldiers and the commander to come to the bivouac at Kamengmi (the people were very well aware of the fact that no more than a brigade could be sent thither). And then attack them at night from all directions.

The Government was however warned early on through spies, and thus Sergeant Veenendal could arrive unexpectedly to Kamengmi after a night's march. Here were about 300 armed people assembled, who shot at the troops with arrows and threw stones at them. A couple of salvos scattered them at flight, and Kamengmi was occupied. Through a couple of night attacks, the rebellious party suffered some $30 \mathrm{dead}$. The peace was quickly restored.

In 1918 a serious uprising took place in the mountain district Limbur-Welai and Mataru, the population of which belonged to the Berawahing group (called orang Bani by the coastal population), whereby the Raja of Alor, Bala Nampira, was murdered during an attack whereby the bivouac where he stayed was set on fire by burning arrows. The reason for the uprising was once again the demands of corvée service and taxation. This uprising was in effect a rebellion in an entire area (Atimelang-Kalaisi and the present Bujaman), whereby the various kampungs stuck together. They were truly fed up with registration, the capture of unregistered persons, the payment of fines, and the harvesting of taxes. As a go-between between themselves and the spirits of the ancestors, they elevated a "sultane" in the kampung Fungwati. This woman called Maleilehi would ensure their victory in the fight against the "compeni" ${ }^{48}$, and sacrifices were frequently made for her at various kampungs, with mokos, gongs, hogs, paddy and jagung. ${ }^{49}$

One by one, Fungwati, Afenbeka and Manet were taken by the Lieutenant W. Muller. These mountain kampungs were strengthened with stone parapets (even three lying each behind the other) of 1,50 meters height, furnished with firing holes, while the access ways were closed with bamboo paggers. ${ }^{50}$ Here the resistance was stronger and the garrisons held out longer. After having been driven out of the "bentengs", the rebels hid in the terrain, sometimes also in other kampongs. When tracked by the brigades, the soldiers were shot at from these hiding places with arrows, or attacked with klewangs. ${ }^{51}$ At kampung Fungwati a band, after having been driven out of the kampung, fortified themselves in a nearby cave for a long time. Through enduring patrolling in the terrain, the remaining rebels reported one by one. After the arrest of the husband of the sultane, the uprising was at an end (October 11, 1918).

47 Big headman.

48 The compeni or company was strictly speaking the Dutch East India Company or VOC, dissolved in 1799/1800 (Ricklefs 1981, p. 106). The term became synonymous with the Dutch establishment in the East Indies in indigenous eyes, and therefore survived until modern times.

49 Maize.

50 Pagger, from Malay pagar, is a fence or fortification.

51 Single-edged sword, cutlass. 
This "Sultane" herself was arrested at Manet (Mataru) after the assault of this kampung, where she lay among the dead and wounded, being taken for dead. At the assault on kampung Manet, the Raja of Kui also participated with his people. A large booty of mokos, gongs, etc., supposedly fell into his hands. There were several attempts to make him return these goods. By the assistant-resident of Endeh, ${ }^{52}$ an investigation was carried out during a tour in 1937. This investigation did not, as expected, yield any results, so that the request for the returning of these goods was rejected..$^{53}$

In 1940 a new investigation took place, by the temukung of Bogalbui and some other chiefs. The investigation undertaken by myself yielded just as little result. The population was told that they had to bear this loss as punishment for their uprising. This old question was once again brought up at the time of the uprising of the mountain people of the same area during the Japanese occupation. ${ }^{54}$

In February 1929 there was just as much unrest in the Atimelang area. Once again it was a "sultan." This time a certain Mali Lakaä of the kampung Atimelang wished to be elevated to "sultan" and had a house (a kind of benteng 55 of stone boulders piled upon each other) built. According to the kapala of kampung Alukawati, this Mali Lakaä had supposedly dreamt that a woman whom he would marry came descending from the sky, after which he would become "sultan." Since the governance was informed, action could be taken early on.

When a mutiny broke out at the military detachment in Kalabahi in March 1942, and as the European officers and under-officers were put to flight, and the European governmental officers with the Indian vicar were taken prisoners by the militaries, a rising quickly broke out in the kapitan-ship Limbur. This rising rapidly spread to the neighbouring kapitan-ship Welai and later to Mataru. This rising was suppressed by the Japanese in a bloody fashion. After their withdrawal in 1945, the rising came to the fore again. This time the rising was suppressed by a police force established in Kalabahi, which was reinforced with 30 men, former militaries of the Royal Netherlands Indies Army from Kupang.

After the first rebellion, the kampong chiefs of Manet and Builola (Mataru) and the temukung of Atimelang, the kapala of Dikingpea and the medicine man Thomas Atalang, all from the kapitan-ship Limbur, were held responsible by the Japanese in the open at Kalabahi. On the following day the temukung of Welai was finished off with the bayonets. The population of these areas blamed the rajas of Alor and Kui for these retributions. (The 3 persons from the Limbur area had reported after they had apparently been promised that they would not be punished.) One may refer to the report by the adspirant-controleur, J.R. Krol, about the risings of the mountain people of Alor against the rajas. After the return of the Dutch Power in November 1945 , there was no sign of any unrest in these quarters. The dispatched patrols were received with joy. When exercising governing authority, one should take into account the fact that the

52 Endeh or Ende was a settlement, today a city, at the south coast of Flores.

53 It should be recalled that the bronze drums called moko and the gongs were highly valued prestige objects.

54 The Japanese occupation lasted 1942-45.

55 Fortress. 
power of the rajas in the mountain areas actually depends on the confidence that the population has in the Dutch governance.

Below follows a short sketch of the emerging of the various landschappen on Alor.

\section{The landschap Alor}

On the Kabola Peninsula there were three coastal settlements, namely Alor-Besar, AlorKecil and Dulolong, which were entirely independent and had each their own governance. The inhabitants of Alor-Besar were supposedly descended from the mountain kampung Oli. The inhabitants of Alor-Kecil and Dulolong had a common ancestor and were supposedly descended from the islet Pulau Rusa, situated between Pantar and Lomblen.

In each settlement there were four holders of authority, namely:

a. The Atabeng, the actual headman of the settlement.

b. The Kapitan, the kepala perang. ${ }^{56}$

c. The Marang, who wielded power in the name of the Atabeng.

d. The Hukung, ${ }^{57}$ to whom all the legal issues were brought.

More important issues were put forward to the Marang for settling, who then brought report about the most important issues to the Atabeng. ${ }^{58}$

About 1850 a Portuguese ship appeared before Alor-Besar, and the Atabeng Kawiha Naha was acknowledged by the Portuguese as raja. ${ }^{59}$ About 1860 , when our governance was established (a posthouder was placed at Alor-Kecil), a close family member of Kawiha Naha called Baololong was acknowledged as raja. ${ }^{60}$

Baololong was married to a sister of the Atabeng of Dulolong. Since Dulolong and AlorKecil were considered kakak-adik ${ }^{61}$ due to their common ancestry, the chiefs of Alor-Kecil and Dulolong agreed to leave the dignity of raja to the chief of Alor-Besar, since the Dutch governance only wished to acknowledge one raja. ${ }^{62}$

56 War chief.

57 From Malay hukum, law or verdict.

58 An appendix to the Van Galen report outlines the pedigree of the Atabeng line. The list of ancestors is: Mauput - Helilolmau - Pelang Helilol - Maupelang - Tobikamang - Kabeka Tobi - Kari - Doti - Kurang - Ago - Baololong - Bakolaha - Doti - Kabeka - Pokomahingmeang - Kawiha Naha - Lau - Tulimau I. The latter seems to have died in 1841, and to have been followed by his uncle Baulolong, mentioned in the text.

59 The event is misdated. According to Portuguese materials, the "king" Cabibá of Allor Grande acknowledged the authority of the Governor of Dili, Victorino Freire da Cunha Gusmão (1812-15) (Rodemeier 2006, p. 78; cf. Castro 1867, pp. 283, 291). Dutch sources indicate that this took place in 1813-14 (ANRI Timor: 37; Kontrak Perjanjian 2007, p. 316).

60 Again the event is misdated. Baololong was a younger son of Kawiha Naha. He took over the position of raja or Atabeng in 1841 and was in power until his death in 1876. He actually came to Kupang in September 1844, thus years before the colonial treaties of division, and was acknowledged as Raja of Alor. Baololong owned a staff with silver weapon which had once been bestowed on his ancestor by the VOC (Sartono Kartodirdjo 1973, p. 419). This presumably took place in the second half of the seventeenth century, when there were a few visits by Dutch merchants and officials to the islands (Hägerdal 2010, pp. 225-30).

61 Elder brother-younger brother.

62 The chiefs or Kapitans of Alor-Kecil and Dulolong were both descended from Saku Bala Dulu, an immigrant from Sulawesi who married a princess of the Munaseli princedom on Pantar. His two grand- 
Baololong was followed by his son Tulimau (contract July 22, 1898 concerning mining rights, declaration 22 August 1901 concerning the levying of taxes). ${ }^{63}$

Raja Tulimau was married to a daughter of Nampira Bukan, from the Hukung family (see above) of Dulolong. ${ }^{64}$

Raja Tulimau was succeeded by a family member called Kawiha Tuli, who signed the Timor Declaration (September 27, 1903, approved by the Governor-General on April 6, 1904). ${ }^{65}$ Due to unfitness Kawiha Tuli was deposed from his position, and the rule was temporarily wielded by Nampira Bukan of Dulolong. A golden "Kopiah Kerajaan" ${ }_{66}$ was bestowed on him about 1900, as an acknowledgement of his efforts to settle a dispute between the Rajas of Kui and Batulolong. About 1890, a staff of dignity with a golden knob (with the inscription Je Mainti$e^{e n d r a i}{ }^{67}$ ) was bestowed upon him at the arrival of a Dutch ship at the roadstead of Dulolong. Although coming from the Hukung family, Nampira Bukan was acknowledged as raja in $\mathrm{Ku}-$ pang, probably as being the most prominent personality.

At his demise in 1915, the son of his fourth wife, Bala Nampira, was acknowledged as raja as being the best fit candidate.

The Short Declaration ${ }^{68}$ of May 9, 1916 was approved by the Governor-General on 25 July 1917.

Raja Bala Nampira was murdered in 1918 at the time of the uprising of the mountaineers in the kampung Fungwati.

During the minority of his son Achmad Bala Nampira, Umar Watang Nampira was appointed temporary Raja of Alor (Short Declaration April 16, 1919. Approved by the Governor-General on October, 14 1919).$^{69}$ Umar Watang Nampira has now submitted his application of retirement in favour of Achmad Bala Nampira.

By decision by the Resident of Timor en Onderhoorigheden on July 7, 1926, No. 297, Umar Watang Nampira was likewise charged with the rule over the landschappen Barnusa and Pantar Matahari Naik. ${ }^{70}$

sons Nae Saku and Johol became Kapitans of Dulolong and Alor-Kecil, respectively (Gomang 1993, p. 30; local pedigree seen by the present writer). Of these persons, Nae Saku of Dulolong is documented in Dutch sources in 1673-77 (Hägerdal 2010, p. 228)

63 Dutch materials indicate that Baololong was first followed by his son Panggo Aman, 1877-95. The capacity of raja was then taken over by a younger son called Tulimau, who governed in 1895-1903. The dates for the rajas here and in later footnotes mostly follow the tables of L.J. van Dijk $(1925,1934)$.

64 According to other sources Nampira Bukan belonged to the family of Kapitans of Dulolong, rather than the Hukungs.

65 He was a grand-nephew of Baololong and governed 1903-08. His father was the Atabeng Tulimau I, who probably died in 1841 .

66 "Cap of the kingdom", a kopiah being a brimless cap worn by Indonesian Muslims.

67 "I will maintain", the motto of the Dutch stadtholder William the Silent and (from 1815) of the Kingdom of the Netherlands.

68 The Korte Verklaring was a terse-worded declaration that the rajas of the Dutch East Indies signed when they accessed power.

$69 \mathrm{He}$ was the son of Watang, a brother of Bala Nampira, and was therefore the first cousin of Achmad Bala Nampira. He was born in 1885 and died in 1960.

70 The Dutch frequently tried to rationalize governance in the Residency Timor en Onderhoorigheden by merging smaller princedoms into larger. Umar Watang Nampira was the caretaker raja until 1952, when he stepped aside for his cousin Achmad Bala Nampira. The self-ruling territories (daerah swapra- 
That the raja family of Alor-Besar did not immediately yield to the [Dutch] acknowledgement of Bala Nampira as raja has already been made clear by the description of military actions on Alor (uprisings under the leadership of Lawano and Bura).

A son of Lawano, namely Mahmud, is now the temukung of Alor-Besar, and a son of Raja Tulimau is Kapitan of Limbur.

Concerning the wielding of ruling power, the raja had at his disposal a Kapitan. Originally that was for the entire landschap. Later, by the intensification and expansion of the governance, there were three Kapitans appointed, namely for the district Dulolong - the so-called Bird's Head - at Kabola Peninsula, where the influence of the chiefs of Dulolong was greatest since old; and over the mountain districts Welai and Limbur.

\section{The landschappen Pandai-Barnusa and Blagar on Pantar Island}

The common ancestor of the raja families of Pandai and Barnusa supposedly came from Java. His name was Mojopahit or Aki Ai. ${ }^{71}$ The legend in question is briefly rendered in the Memorie van Overgave by the former administrator of Alor, K. Rijnders.

A more extended account, also about the former neighbouring raja-ship Muna Seli at the east coast of Pantar, may be found at the sub-regional office, assembled by the administration scribe A.B. Talib. Muna Seli was, on the occasion of a dispute with Pandai, completely ravaged, while the population was scattered all over Alor and Pantar. ${ }^{72}$

The common ancestor of the raja families of Pandai and Barnusa would have come from Java. He begot five sons. The oldest, Baramauwolang, settled in the vicinity of the present Blangmerang, and was the ancestor of the raja family of Barnusa. The second son, Daimauwolang, established the kampong Dinanglain or Pandai and was the ancestor of the raja family there.

Tulimauwolang settled at Alor-Besar. The two other brothers went to Lomblen and established the kampong Lewabala. ${ }^{73}$

The first Raja of Pandai who was acknowledged by the Portuguese was Bapa Boka. ${ }^{74}$

ja) were kept for some years after the independence of Indonesia. Achmad wielded authority from 1952 to 1962, when the traditional forms of governance in this part of Indonesia were abolished. Nevertheless, he continued governing as camat (district head) from 1962 to 1971, dying in 1998.

71 According to a variant, Mojopahit and Aki Ai were actually brothers. Mojopahit refers to the Majapahit Empire that was centred in Java in 1293-c. 1527 but supposedly encompassed much of the Southeast Asian archipelago (Ricklefs 1981, pp. 16-8). Local tales of Majapahit origins testify to its great prestige in the eyes of later generations. Such origin stories are found in many societies of Indonesia, including some in the eastern parts (Savu, Flores, etc.) (Mailrapport 1877: 483, Nationaal Archief, The Hague).

72 Talib's material has been used by Annie Lemoine (1969) and by Susanne Rodemeier, who provides an extended discussion about the Munaseli princedom (Rodemeier 2006, pp. 265-311). Munaseli was supposedly destroyed by a Javanse incursion.

73 Lewabala or Labala was the only princedom on Lembata (Lomblen), part of the Solor Islands. Local traditions from Labala confirm that the settlement originated from a migration from Munaseli (Boli Lajar 2007).

74 According to Portuguese material, the "king" of Pandai, Manhola, acknowledged Portuguese authority in c. 1814 (Rodemeier 2006, p. 78). Later, in 1832, the name of the Raja of Pandai was Hukum (Francis, unpublished report, H 548, KITLV Archive). 
His son Pela Boka was the first raja who was acknowledged by the Dutch Indies Government. He was succeeded by his younger brother Salama Boka. ${ }^{75}$ His son, Beng Hukung, signed a contract about mining rights on July 22, 1898, and signed the Timor Declaration on 22 August 1901 (approved and confirmed by governmental decision of April 3, 1901, No. 8). Finally he signed yet another declaration about the imposition of taxes, also on August 22, $1901 .{ }^{76}$ At his death the rule over the landschap Pandai was entrusted to Sinung Maleng of the raja family of Pandai.

About 1911 he was, due to sickness, replaced by his Kapitan (not in the sense of kepala perang), Koliamang Wono, who signed the "Short Declaration" on November 2, 1918 (approved by governmental decision on April 7, 1919), as ruler of the landschap Pantar Matahari Naik, ${ }^{77}$ which was formed by a merger between the landschappen Pandai and Blagar.

On request, Raja Koliamang was discharged with a pension in 1926, and the caretaking of the rule over the landschap Pantar Matahari Naik was, by decision of the Resident of Timor en Onderhoorigheden of July 7, 1926, No. 297, entrusted to Umar Watang Nampira, caretaker raja of the landschap Alor. ${ }^{78}$

The son of Raja Koliamang Wono, Anwar, was appointed Kapitan of Pantar Matahari Naik in 1939. But he had to be deposed at the end of 1945 due to complaints of the people over his behavior. A son of the Raja of Blagar, Tahir Noke, has in the meanwhile been made Kapitan of Pantar Matahari Naik.

The first Raja of Barnusa who was acknowledged by the Netherlands Indies Government was Aku Boli. ${ }^{79} \mathrm{He}$ was succeeded by Baso Aku, his son. ${ }^{80}$ His son Koliamang Baso signed the Timor Declaration on June 3, 1896 (approved and confirmed by governmental decision on November 17, 1896, No. 12), a contract about mining rights on July 22, 1898, and a declaration about the imposition of taxes on August 22, 1901. On his own request he stepped down in 1926

75 When tracing Pandai's history, Van Galen apparently makes use of oral accounts which do not quite fit with contemporary documents. In December 1848 Slamat (Salama), a son of the deceased Raja of Pandai (Hukum?), arrived to Kupang and was acknowledged as the right successor (Sartono Kartodirdjo 1973, p. 420). However, a dispute arose between Slamat and his uncle Bokka (Bapa Boka of Van Galen's text). Bokka tried to strengthen his powers at the expense of Slamat by gaining support from Palembang, the raja of the Solorese princedom Lamakera. In October 1853 the Dutch authorities lost patience with the internal troubles and sent an armed expedition to Pandai. The expedition took Bokka in custody and brought him to Kupang (ANRI Timor: 96). Bokka's son was Pellah (Pela Boka) who assisted his father in his designs (Kontrak Perjanjian 2007, p. 356). Pela and Salama-Slamat were thus cousins, not literally brothers. Slamat ruled, at least intermittently, from 1848 to 1877.

76 Beng Hukung ruled from 1878 to 1901.

77 A Malay name meaning "Rising Sun Pantar"; in other words, eastern Pantar as opposed to Barnusa in western Pantar.

78 As we have seen, he governed until 1952, being replaced by his cousin Achmad Bala Nampira. Raja rule was abolished in the entire area by governmental decision in 1962.

79 Aku Boli was also known as Achbar. According to the pedigree of the princely family, he represented the twelfth generation of lords of Barnusa (Baranusa). The filiation is: Bara Mauwolong - Mau Bara I - Boli Mau - Mau Boli I - Bara Mau - Mau Bara II - Tonda Boli I - Boli Tonda - Mau Boli II - Tonda Boli II - Boli Tonda, the father of Aku Boli. I am grateful to Mr. Ivan Taniputera for showing me this pedigree. Boli flourished as raja in 1832 (Francis, unpublished report, H 548, KITLV Archive). In October $1848 \mathrm{Aku}$ Boli succeeded to the dignity and received a ceremonial staff and a flag (Sartono Kartodirdjo 1973, p. 420). He governed until 1877.

80 This person governed in 1878-95. 
and received a pension, ${ }^{81}$ and the rule over the landschap Barnusa was entrusted the caretaker raja of Alor, Umar Watang Nampira (decision of the Resident of Timor of July 7, 1926, No. 297). Raja Koliamang Wono was supported in his rule over the landschap Barnusa by Kapitan Minta. He was succeeded by the kepala besar Amu Blegur of the mountain population between Blangmerang and Kayang, the so-called Lemma group. He was in turn succeeded by his son Amu Blegur, a Christian. His power in the Mohammedan coastal kampong Blangmerang is small. ${ }^{82}$

In the territory Blagar there were three coastal settlements, namely Bakalan, Kolijahi, and Tuaäbang.

At the arrival of the Portuguese in Pandai, a chief from Tuaäbang was the first one to report, and in return he received a flag.

At the later arrival of the Netherlands Indies Government, the chief of Bakalan reported, and he was acknowledged by us. ${ }^{83}$

Raja Salama Noke signed the Timor Declaration on June 3, 1896 (approved and confirmed by governmental decision of 17 November 1896, No. 12), a contract about mining rights on July 22, 1898, and a declaration about the imposition of taxes on August 22, 1901.

He was followed by Raja Noke Salama. He was discharged from rule due to sickness. ${ }^{84}$ The landschap Blagar was then merged with Pandai, into the landschap Pantar Matahari Naik under Raja Koliamang Wono (see above).

The Raja of Blagar had a Kapitan at his disposal. These masters, however, had to be deposed, one after the other, due to committed oppression. A son of Raja Noke Salama called Tahir Noke is now the Kapitan of Pantar Matahari Naik. ${ }^{85}$

81 He passed away in 1952. He had six sons, of which the eldest, Mangkup Raja Baso, later held the function of Kapitan. The latter passed away in 1972.

82 Bell 2009, pp. 50-1, adds some details about the traditional structure of Barnusa. The maritime profile of the princedom was accentuated by the state perahus (perahu kerajaan) kept by the central authority. The centre of the domain was initially Waiwagang but was later moved to Barnusa, which was also called Piring Sina (Chinese Plate) since it was orderly organized. In Barnusa there were eight principal suku (clans) which traditionally had various assigned tasks.

83 The traditional history of Blagar (Belagar) is traced in an unpublushed manuscript by M.U. Sogo (n.d.). According to this text, the first raja was a Maka Pala who must have flourished in the first half of the nineteenth century. However, other sources make clear that Blagar existed long before; it is expressly mentioned as a polity in 1673 (Hägerdal 2010, p. 226). Maka Pala's son Keibara is known to have been acknowledged by the Dutch authorities on 23 June 1850 . Two years later he turned defiant and left back the insignia of his raja dignity that he had received from the Dutch (Kontrak Perjanjian 2007, p. 356). Finally the Dutch Resident in Kupang decided to send 200 auxiliaries from the island Rote to deal with Keibara and the likewise defiant Bokka of Pandai. It was common practice in the Timor Residency to fight Indonesians with Indonesians rather than to dispatch expensive European troops. Keibara was declared deposed in the fall of 1853 and replaced with his brother Leing Date (1853-91) (ANRI Timor: 61). Leing Date was unwilling to extradite the fallen raja to the Dutch in Kupang, but otherwise had a more amenable relation to the colonial authorities (ANRI Timor: 96). He was succeeded by his sons Koli (1892-95) and Salama Noke (1896-1917).

84 His dates are 1917-18.

85 Tahir Noke was the Kapitan of Pantar Matahari Naik from 1946 to 1964 and died in 2001. 


\section{The landschappen Kolana and Pureman}

The common ancestor of the raja families of Kolana and Pureman, called Sinimau, came from Kalong (Abui) in the landschap Kui (the present kapitan-ship Probur). ${ }^{86}$ His wife Maria was a daughter of the Raja of Muna Seli (Pantar). They fled from Kalong due to a smallpox epidemic.

They settled in Maumana (Pureman) after a period of roving around. ${ }^{87}$

Some generations later, Tubulau begot two sons, namely Lupuimakuni and Makunimau. The youngest settled at Tanjung Lisomu. His descendants finally, after repeated moves caused by wars with the mountaineers (Tanglapui), settled in the present kampung Manabala (Kolana). ${ }^{88}$

The first Raja of Kolana who was acknowledged by the Netherlands Indies Government, was Mautuku, who signed the Timor Declaration (May 12, 1889. Approved by the GovernorGeneral on July 10, 1889) ${ }^{89}$ He signed a declaration about mining rights on July 22, 1898, and a declaration about the imposition of taxes on August 22, 1901.

He was succeeded by his son Alexander Makunimau, who signed the Short Declaration on June 20, 1914, approved and confirmed by governmental decision on August 27, 1915. ${ }^{90}$ By decision of the Resident of Timor en Onderhoorigheden on July 11, 1927, No. 250, he was also entrusted with the rule over the landschap Pureman (see below).

By decision of the Governor-General of January 13, 1933, No. 27, Raja Alexander Makunimau was honourably discharged due to his advanced age, and his younger brother Christoffel Makunimau (Kari Mudi) was entrusted the temporary rule over the landschap Kolana during the minority of Marcus Makunimau, eldest son of Raja Alexander. By decision of the Resident of Timor en Onderhoorigheden of February 2, 1933, No. 22, Christoffel was also entrusted the rule over the landschap Pureman. (During the war, Christoffel Makunimau was deposed by the Japanese (July 1, 1944) and Marcus Makunimau was appointed as his successor). By decision of the Conica ${ }^{91}$ of Timor on April 8, 1946, No. 73, Christoffel was discharged due to bodily

86 Abui is depicted as a very ancient princedom in its own right in some traditions. It was subsequently weakened since the brothers of the ruler preferred to migrate to other places on Alor and Pantar, one of them being the founder of Munaseli (Bell 2009, p. 32-35). Kalong is still mentioned as a separate domain in the report of Emanuel Francis in 1832, having a population of 800 fit men or 2,400 inhabitants in total (H 548, KITLV Archive).

87 The pedigree of Pureman leaders is outlined in an appendix of the text. It runs: Sini Mau Laka Tubul Sini Mau - Sini Mau II - Tubu Lau I - Sini Mau III - Tubu Lau II - Sini Mau IV - Tubu Lau III - Lupuimakuni - Tubu Lau IV - Painteri I - Resi Bera - Tubu Lau V - Painteri II - Malaikari I - Tubu Lau VI - Molana - Tubu Lau VII. The latter was followed by his brother Alobana and the latter's son Malaikari II, mentioned in the text.

88 According to an appendix in Van Galen's text, the line of chiefs of Kolana were: Makunimau I Takalama Kunimau - Makuing Takalama Kaing - Mautuka I - Makunimau II - Mautuka II - Makunimau III - Mautuka III. The latter is mentioned in the text, as ruling from before 1889 to 1914. He stepped down and died in 1916.

89 Although Kolana was technically speaking part of the Dutch East Indies since 1851, the raja still for a long time paid homage to the Portuguese, or rather to the Portuguese vassals Oecussi and Liquiçá on Timor's north coast. This went on until about 1880. At this time Kolana only encompassed four kampungs (Mailrapport 1880: 333, Nationaal Archief, The Hague).

90 Mautuku or Mautuka stepped down in 1914 and passed away in 1916.

91 Chief Commanding Officer of NICA (Netherlands Indies Civil Administration). 
unfitness, and Marcus Makunimau was temporarily entrusted the rule over the landschappen Kolana and Pureman (see pedigree). ${ }^{92}$

The first Raja of Pureman who was acknowledged by the Netherlands Indies Government was Malaikari, who signed the Timor Declaration on October 30, 1891 (approved on January 29, 1892). A contract concerning mining rights [was signed] on June 13, 1900 (approved on August 6, 1900). A declaration concerning the imposition of taxes [was signed] on August 31, 1901 (approved on December 21, 1901).

About 1918 he was exiled to Pantar. Probably due to the lack of fit candidates among the raja family, a certain Besi Laku, originating from the kampong Paitoko (Pureman), was appointed raja. He signed the Short Declaration on December 27, 1918, approved by governmental decision on October 14, 1919.

By decision of the Resident of Timor on July, 11 1927, No. 250, Besi Laku was honourably retired "on request", and the rule over the landschap Pureman was entrusted to Raja Alexander Makunimau (see above).

By decision of the Conica of Timor on April 8, 1946, No. 73, Marcus Makunimau was entrusted with the rule over the landschap Pureman (see above). Descendants of the raja family of Pureman still live in the insignificant coastal settlement Pureman. One of them is now temukung (see pedigree). Their influence is small. The Rajas of Kolana and Pureman had a Kapitan at disposal for the execution of their governance. The landschap Kolana was later on split into two kapitan-ships or districts, namely Kolana nad Taramana. The son of Raja Besi Laku is the Kapitan of Pureman.

\section{The landschap Batulolong}

The ancestor of the raja family of Batulolong supposedly came from a place called Luka Bekeka in the vicinity of Timor-Dilly. ${ }^{93}$ According to the stories, a woman called Loni Enam had six sons. When these sons, having grown up, insisted to know who their father was, she told them that their father was an Ular Naga. ${ }^{94}$ When he suddenly appeared in the shape of a blinding light, the six brothers fled away.

The eldest fled to Alor Batulolong, the second fled to Likusan, the third to Liurai, the fourth to Watubora, the fifth remained in Luka, and the sixth to OEkusi. ${ }^{95}$

92 Marcus Makunimau was in charge from 1944 to 1962, when the traditional raja system was abolished. He passed away in 1996. Christoffel Makunimau's son Willem was camat (district head) from 1962 to 1966 . Members of the old raja families of eastern Indonesia have often been used as bureaucratic officials until present time.

93 Luka Bekeka seems to reflect the Timorese princedoms Luca and Viqueque in south-eastern Timor, which are actually far removed from Dilly (Dili).

94 That is, a naga snake. Nagas often have a prominent role in myths and legends of Indonesia.

95 These are places on Timor. Likusan or Likusaen or Liquiçá is a coastal town in north-western Timor Leste. Liurai may allude to the prominent princedom Wewiku-Wehali in Indonesian Timor, seat of the original Liurai (ruler). Watubora is Fatuboro in north-western Timor Leste. Luka or Luca is a prestigious princedom in the south-east. OEkusi, more commonly Oecussi, is a princedom of Timor Leste which is situated in the enclave in western Timor. 
The eldest, called Kepamakani, came, after many wanderings over Alor Island, finally to Batulolong-Kiraman on the coast, and was acknowledged by the inhabitants there as their chief. The first raja acknowledged by the Portuguese was Karimalei Gapada. ${ }^{96}$

This raja was succeeded by Kamusawen (Chaspar) Karimalei, who signed the Timor Declaration on November 23, 1897, approved by governmental decision on January 31, 1898.

In 1914 he was succeeded by Resi Bera who signed the Short Declaration on August 29, 1914 (approved by governmental decision on August 27, 1915). Resi Bera was honourably discharged in 1937 due to advanced age, and succeeded by his son Wilhelmus Awengkari. The Short Declaration was sworn on November 12, 1937, approved on July 13, 1938.

Wilhelmus Awengkari passed away on August 11, 1941. Due to the lack of suitable candidates among the raja family, the Kapitan of Batulolong, Christoffel Laubala, was temporarily entrusted the rule over the landschap Batulolong, decision of the Resident on November 20, 1941, No. 59/XII/Z.E.Z. ${ }^{97}$ During the war, Laubala asked to retire because of the inconsiderate treatment by the Japanese, and Lourens Karimalei was appointed raja.

Lourens Karimalei is descended from another branch of the raja family of Batulolong (see pedigree). ${ }^{98}$ The son of Raja Wilhelmus Awengkari, Johan, now about 20 years old, is somewhat quick-tempered and is unfit as successor.

Christoffel Laubala has been restored to his original function as Kapitan. ${ }^{99}$

\section{[V.] The landschappen Kui and Mataru}

The ancestor of the raja family of Kui came from Endeh, and finally, after many wanderings over Alor, settled in Lerabaing and was acknowledged by the inhabitants there as chief = raja. $^{100}$

\section{Lerabaing at first stood under Portuguese influence. ${ }^{101}$}

96 According to the traditional account, he was the seventeenth Raja of Batulolong. He ruled from the mid-nineteenth century to 1897 . According to a handwritten local manuscript seen by the translator, the predecessors as chiefs of Batulolong were Karlau Kep, Maleikari I, Awenlo, Awengkari I, Losa, Asakamen, Laubana, Maleikari II, Lauika, Karlau, Kamusawen I, Karimaley, Sarata, Makunimau, Laukosi. The successor of the latter was Karimalei Gapada, who died in 1897. He had several sons of which Chasper succeeded him. The following raja Alfonsus Resi Bera was a son of Chasper's elder brother Hanoch.

97 This person was a younger brother of Alfonsus Resi Bera.

98 Lourens Karimalei was once again appointed raja by the Dutch authorities in 1947, and kept the title until the end of the raja system in 1962. He passed away in 1996. He was a son of Menase, a younger brother of Chasper.

99 His term as caretaker of the Batulolong princedom ended in 1947, when Lourens Karimalei acceded.

100 The appendix to Van Galen's text outlines the pedigree of the Kui lords: Maleikili - Maleilok - Gawamalei - Atamalei - Maleilok - Banla - Pasoma - Maleikili - Kinanggi - Maleilok - Pasoma Gawamalei - Banla - Atamalei - Gawamalei - Maleilok - Banla - Kinanggi - Banla - Pasoma - Atamalei - Maleikili - Atamalei - Pssoma - Kinanggi - Atsom - Pasoma - Kinanggi - Banla - Gawamalei - Banla - Pasoma (or Pui Soma). The latter is known to have reigned as raja in 1855-91. He had an elder brother Atamalei, whose son Kinanggi was the father of the three rajas Taru Soma I, Goamalei and Katang Koli.

101 Unlike Pureman, Kolana, Mataru and Batulolong, Kui was actually a member of the Galiyao league since old. However, it tended to avoid contacts with the Dutch authorities, and was clearly pro- 
At the arrival of the Dutch around 1850 or 1860 , the shelling by a warship was necessary at first, before they [the local population] acknowledged the Dutch governance. ${ }^{102}$ One of the cannon balls is still present.

The first raja who signed the Timor declaration was Goamalei on November 23, 1897 (approved on January 31, 1898). ${ }^{103}$ He signed a contract about mining rights on July 22, 1898 and a declaration about the imposition of taxes on August 22, 1901.

He was followed by Raja Taru Soma. ${ }^{104}$ This one was succeeded by his brother DaEng Soma, who signed the Short Declaration on June 4, 1918 (approved on September 13, 1918). After his demise (he committed suicide), Katang Koli was entrusted the caretaking of the rule over the landschap Kui. ${ }^{105}$ The Short Declaration [was signed] on April 12, 1922 (approved March 13, 1923).

By decision of the Governor-General on March 7, 1939, No. 29, Katang Koli was honourably discharged on request. (He passed away on November 14, 1942.) By decision of the Resident of Timor en Onderhoorigheden of March 24, 1939, No. 1/XII/Z.B.Z., his son Banla Kinanggi was temporarily entrusted with the caretaking of the rule over the landschap Kui, with the aim that he would be definitively appointed as self-ruler after his fitness had been confirmed. A request concerning this was submitted by a letter on December 15, 1946, No. ... [illegible]. ${ }^{106}$

The ancestor of the raja family of Mataru supposedly came from Timor, from the kampung Wuka in the vicinity of Atapupu. ${ }^{107}$

The first Raja of Mataru who signed the Timor Declaration was Raka Lakussi on September 4, 1877, approved by governmental decision on December 7, 1877, No. 7. ${ }^{108}$ A contract concerning mining rights [was signed] on July 22,1898 , and a declaration concerning the imposition of taxes on August 22, 1901. By governmental decision of February 12, 1916, No. 4, this insignificant landschap (3,400 souls) was abrogated and incorporated into the landschap Kui. This

Portuguese during much of the nineteenth century. Supposedly, it was tied to the Portuguese from 1844 (Van Lijnden 1851; Hägerdal 2010, p. 237).

102 The incident took place on January 10,1855 , less than four years after the transfer of suzerainty from Portugal. The local raja Gesi absolutely refused to yield to the Dutch demands to submit, and the kampung was, as a consequence, shelled and burnt to the ground (ANRI Timor: 118). The locals then deposed Gesi and elevated his nephew Pui Soma or Pasoma to the dignity. He arrived to Kupang in April and received a Dutch tricolour. Pui Soma ruled from 1855 to 1891 but was not an obedient vassal from the Dutch point of view. As late as in c. 1880 he paid an annual tribute to Oecussi in Portuguese Timor (Mailrapport 1880: 333, Nationaal Archief, The Hague). Pui Soma was succeeded by his grand-nephew Taru Soma I, 1892-97.

103 Goamalei was the brother and successor of Taru Soma I and ruled as raja in 1897-1916.

104 Taru Soma II was the son of Taru Soma I and ruled 1916-17.

105 Katang Koli was a brother of Taru Soma I and Goamalei. He ruled from 1921 to 1939, dying in 1942.

106 Banla Kinanggi then ruled as raja from 1946 to his death in 1959. He was the last traditional leader of Kui.

107 Atapupu is a small inlet on the north coast of Timor where a port town has evolved.

108 Lakussi was the first Alorese raja to sign such a contract. Nevertheless, the history of Mataru is obscure. The Dutch expedition of Caspar Reinwardt in 1821 met with an unfriendly reception by the inhabitants of Mataru (Bik, H 601, KITLV Archive). In 1851 the name of the raja was Pesereh, a chief who did neither stand under Dutch nor Portuguese flag (Van Lijnden 1851, p. 336). 
merger occurred because of the exile of the Raja Thomas Solokale to Sumatra due to oppression perpetrated by him.

The landschap Kui originally had only one Kapitan, namely the Kapitan of Lerabaing. Later, under Raja Taru Soma, the so-called Kalong area (Probur) to which the Rajas of Alor made claims, was brought under the landschap Kui, and the kapitan-ship of Probur was installed. After the incorporation of the landschap Mataru it was considered to be a kapitan-ship. Someone from Lerabaing was appointed Kapitan. Later the exiled Raja Thomas Solokale was once again appointed Kapitan. During the war he was deposed and replaced by Balsasar Sukorkoli, someone from the former Kapitan family of Mataru.

The present Kapitan of Probur belongs to the chiefly family of Mataraben, one of the original (mother) kampungs, and as such he has quite a lot of influence.

\section{GEOGRAPHICAL DESCRIPTION}

\section{A. Situation, size, borders}

The onderafdeeling Alor encompasses the following islands:

1. Alor with the islets belonging to it, namely Nuhaben and Sikka or Suwanggi at the north; Sumira at the east; Pura, Rota, Tareweng ${ }^{109}$, Kisu at the west of Alor. ${ }^{110}$

2. Pantar with the islets belonging to it, namely Lapang Batang to the north-west; Pulau Rusa, Marica ${ }^{111}$ and Kambing to the west of Pantar (see moreover the topographical map).

The size of the onderafdeeling is, at least according to the extant topographical map, to be estimated at 230 square kilometres (of which the island Alor alone comprises about two thirds). ${ }^{12}$ The size of each landschap is hard to tell, the more so since the borders have hardly ever been internally established. The extant topographical map illustrates the extension of the various landschappen in the clearest way.

\section{B. General situation of the ground}

Regarding the forms of Alor Island, it must have been the subject of a violent play of nature in times past. The southern part of the island is volcanic with the exception of small limestone rocks at the coasts, whereby it can be deduced from the forms of the stone that the volcanic impact occurred after this part had emerged from the sea.

Apart from a few extant hot water springs, as in Taramana, Kolana and Takala, one also encounters eruptive conglomerates along the coast. The entire north and south coasts consist

109 In old times the island Tareweng or Tereweng gave its name to the strait between Alor and Pantar, today usually known as the Pantar Strait (Hägerdal 2010, p. 227).

110 Baron van Lijnden's enumeration of islands in the Alor Strait between Lembata and Pantar is: Pulau Lapan, Pulau Batan, Nuhakan (pulau Rusa), and Nebatan (Pulau Babi). In the Pantar Strait: Pulau Tawein (Tereweng), Pulau Pura, Pulau Suanggi, Pulau Ternate, and Pulau Pajang (I have modernized the baron's spellings) (Van Lijnden 1851, p. 329).

111 The name Marica or Marisa was formerly sometimes used for the strait between Lembata and Pantar, nowadays the Alor Strait (Hägerdal 2010, p. 227).

112 This is a curious mistake. The area of the Alor islands is estimated at 2,865 square kilometres. 
of such stone. Sandy coastlines are thus rare; a few incoherent parts consist of sand but the rest of stones. Where there is no greater erosion on these stones, the ground is covered; not by the everywhere sprouting alang-alang, but with a finer sort of grass, the so-called "deer grass".

The peninsula "the Bird Head" of Alor consists mostly of coral stone. Along the coasts of that peninsula great reefs occur, but nowhere else. The peninsula is connected with the southern part of Alor by a plain, six kilometres wide, partly consisting of coral, and partly of clay. Probably this connection was formed after the emerging from the sea.

In general the ground may be called fertile, especially in the mountains where the earth consists of eroded volcanic stones covered with a humus layer. The "Bird Head" is less fertile, so here the ladangs ${ }^{113}$ mostly have to be placed between great karang ${ }^{114}$ pieces. The entire island is extraordinarily heavily accidental in form. A certain systematic-ness in the appearance of the mountains cannot be denied, but the ridges, summits and ravines with mostly quite steep sides lie helter-skelter through each other, and the whole thing gives a very confused impression.

\section{Coasts}

The coastline forms an irregular meandering line, which includes more or less deep petty bays and inlets. In general the coasts of the southern and eastern sides do not offer any good anchorages for larger ships, due to the land that dips steeply into the sea. ${ }^{115}$ An exceptional anchorage is offered by the 15 kilometres long Kabola Bay where Kalabahi is situated and which is divided into an outer and an inner bay. Both bays offer safe anchor places for the largest ships; for example the "Franconia" (20,000 tonnes) can easily cast anchor there.

Along the entire coast, apart from the coast between Lerabaing and Mataru (south coast of Alor) and between Kokar and Binlelang (north coast of Alor) besides the west coast of Alor, one encounters non-hardened roads on which one is able to ride in all seasons. A road along the first-mentioned roadless part could not be built without great costs for explosives; while a road along the two latter parts is not urgent.

\section{Plains}

Along the coast one finds the following plains:

1. Along the coast from Kanarilang (4 kilometers west of the Kalabahi Bay) to the kampung Moru (situated at the upper side of the bay opposite Kalabahi);

2. The connection between the "Bird Head" of Alor and South Alor:

3. At Pancoran (situated at the west-south-west, at the upper side of the bay);

4. By Buraga (south coast of Kui);

113 Ladang is a dry rice field, as opposed to the irrigated sawah fields. Ladang cultivation is the simplest form of rice cultivation (Gonggrijp 1934, p. 1252).

114 Reef.

115 According to the account of Baron van Lijnden (1851, p. 330) the boats from Sulawesi called padewakang could lie in the roadstead of the most of the coastal kampungs of Alor's south coast; only the crew must fasten the anchor at the shore since the coast was so steep and without good anchorage. 
5. Close to Batulolong;

6. Close to Mademang (about 7 kilometers east of Batulolong);

7. Close to Peitoko;

8. North of Kolana (east coast of Alor);

9. Close to Adagai (north coast of Alor, about 8 kilometers west of Taramana);

10. Close to Limbur (north coast of Alor, about 6 kilometers west of Adagai);

11. Close to Kokar (north-western coast of the "Bird Head").

On most of these plains, alang-alang ${ }^{116}$ and kayu putih trees ${ }^{117}$ grow, and here and there in between an Alorese has made an illegal ladang. However, the earth in these plains is of good quality (apart from those of Buraga and Pancoran), since the humus of the mountains flows down and is gathered on these plains. ${ }^{118}$

In the mountain areas one encounters the following highland plains:

1. Close to Bujanta and Nihing (both in the "Bird Head"),

2. The plain of Mainang (see under agriculture and agricultural survey),

3. The plain of Kelaisi (idem),

4. The plain of Tanglafui or Lantoka (idem).

We will come back to these plains in more detail under the section "agriculture".

\section{POPULATION}

\section{A. Ancestry, tribe and class division}

The mountain population of middle Alor and the Kabola peninsula, and large groups among the mountain population of Pantar, can be labelled as autochtonous. According to the stories of the people their ancestors were formed out of clay which took human form, out of a hole in the ground, from a mixture of animals and sea snakes, crocodiles, birds, etc. The population of eastern and southern Alor is supposedly mostly descended from Timor. ${ }^{119}$ The Muhammedan coastal population of the district Dulolong and the Muhammedan coastal kampungs on Pantar and Blangmerang and Dinanglain are mostly descended from the Solor Islands, South Celebes (Buton), Sumbawa, etc. Some of these skipper's tales are noted down in the Memorie van Overgave of the former headman K. Rijnders.

The smallest unity from which the population is organized is the kin group. It is very probable that each kin group formerly lived apart from the other, and that it was only later that several kin groups went to live in one kampong. Among the mountain population one often encounters a threefold governance, namely:

116 A tall, coarse type of grass.

117 "Whitewood", the melaleuca cajuputi tree. It has, among other things, medical uses.

118 Baron van Lijnden commented in the mid nineteenth century that the mountain people were "very eager agriculturists" and that the quality of the soil was good enough to ensure deliveries of rice and maize to Timor and Buton Binongko (Van Lijnden 1851, p. 331). The state of agriculture is expanded on in detail in the second part of Van Galen's report.

119 Until recently there was actually a steady flow of people between Alor, Ataúro Island, and eastern Timor. This is also reflected by some of the origin stories of the Alorese princedoms, recounted above. 
a. The actual tribal chief, who regulated all thing that specifically concerned the kin group, such as marriages, bridewealth, mortuary feasts, etc.

b. The orang-kaya $a^{120}$, mostly the richest and most influential person, who carried out the daily governance and represented the kin group vis-à-vis the outer world.

c. The war headman, a function that speaks for itself.

If several kin groups lived among each other, then these functions were often shared up between the kin groups. In the latter case, the kin groups however remained completely independent as regards their own family affairs, which state of things is still almost unchanged.

Among the coastal population of Dulolong one 4 dignities can be found, namely:

a. The atabeng, the kin chief, who did not exercise any actual power. As tribal chief he received a part of the harvest, a fixed part of the hunting prey, etc.

b. The marang, who carried out the daily governance in cooperation with

c. The hukung, to whom all the matters concerning governance of the settlement were presented, and who convened closer with the marang for important issues.

d. The kapitan or war headman.

Every kin group has got its own kin house and lego-lego ${ }^{121}$ (dance) place. The names of the kin groups, kin houses, and persons of authority are enumerated in the appendix (taken from the Memorie of Rijnders).

If a kin group expanded, then groups would break away and form their own kin groups. In Dulolong and Kolana marriages between members of the kin groups with the same ancestor are forbidden. By the mountain population one only encounters a marital bond within the kin group (exogamy ${ }^{122}$ ). If the newly formed kin groups settle in their own settlements, then these become entirely independent. Certainly the head of the mother kampong will still be acknowledged at grand family feasts, and they will lend each other support in war. However, the bond is still very loose.

Of class division there is no question. Certainly slaves were formerly taken during the mutual wars, and people still know, for example in Dulolong, who is descended from these slaves. In the practice of daily life, this makes no difference. It is only in marital issues that it still plays a role.

\section{B. Strength of population and other data}

According to the census of 1930 , the total number of the indigenous population was 90,147 souls, divided into 44,863 males and 45,554 females. ${ }^{123}$ According to the recapitulation statements of the taxation in 1937 and 1946, the numbers were as follows:

120 In Malay, literally "rich man". The term was often used in Indonesian societies for persons of local influence or wealth.

121 Lego-lego is a ring dance that can go on for an extended time, and which is performed at certain places. More information about this important cultural expression will follow in part 2 of this translation.

122 Obviously an error for endogamy. Exogamy means marrying outside one's own group, endogamy is on the contrary a pattern of marriage within a particular ethnic, social or kin group.

123 The Dutch commissioner Emanuel Francis collected some probably unreliable statistical data in his report from 1832 (H 548, KITLV Archive). By this time Alor (Proper) had 6,000 inhabitants, Ika 


\begin{tabular}{lrrrrrr} 
& & Alor & Kui & Kolana & Batulolong & Total \\
Men & 1937 & 13,188 & 5,571 & 4,754 & 1,827 & 25,340 \\
& 1946 & 13,028 & 4,710 & 4,827 & 1,766 & 24,331 \\
Boys & 1937 & 9,195 & 2,548 & 2,696 & 1,010 & 15,446 \\
& 1946 & 12,227 & 3,121 & 3,816 & 1,406 & 20,570 \\
Women & 1937 & 11,447 & 4,246 & 3,690 & 1,523 & 19,924 \\
& 1946 & 13,602 & 4,992 & 5,265 & 1,935 & 25,794 \\
Girls & 1937 & 8,068 & 1,576 & 2,118 & 855 & 12,617 \\
& 1946 & 10,989 & 2,441 & 3,043 & 1,198 & 17,711 \\
\multirow{2}{*}{ Total } & 1937 & 41,896 & 13,931 & 13,257 & 5,215 & 74,299 \\
& 1946 & 49,846 & 15,304 & 16,951 & 6,305 & 88,406
\end{tabular}

The decrease of the number of men, particularly in the landschap Kui, is notable. Certainly there were a large number of victims in Mataru during the uprisings in 1942 and 1943 (the aspirant-controller Krol mentioned between 150 and 200) but that does not explain a decrease of 861 people. Also the landschappen Alor and Batulolong show a decrease. Only the landschap Kolana provides an increase of 73 men. One reason for this decrease is certainly the large number of victims among the Alorese, who were transported as coolies to Dutch and Portuguese Timor during the war. ${ }^{124}$ A possible reason is people withdrawing from taxation and registration, which is easier when the former pass control does not exist anymore. This number, however, cannot be large. The number of boys, women and girls shows an increase of 34,29 and 41 per cent. The entire number of souls has risen with 20 per cent. ${ }^{125}$

\section{RELIGION}

The population of the Onderafdeeling Alor consists of pagans, Christians and Muhammedans. The number of pagans is decreasing. During the war a certain reverting to paganism

Raka (?) 800, Batulolong 400, Kui 320, Kalong 3,200, Hamapu 3,000, Delluntuw (?) 320, Pandai 1,000, Barnusa 4,000, and Blagar 9,200. that would make 17,240 on Alor and 15,200 in Pantar, but some of the areas of Alor do not seem to have been included. Scattered population data are also given by Baron van Lijnden in 1851, p. 335-6. At that time Pandai had 275 inhabitants plus an unknown number of mountain people; Barnusa had 626, Blagar 2,074, and Alor as much as 3,645 plus the mountain people. No figures were given for the other domains. The great differences between the figures of Francis' and Van Lijnden's accounts suggest some cautiousness here. Such as they are the numbers suggest a substantial increase in the colonial period.

124 Large numbers of native Indonesians were conscripted by the Japanese authorities as coolies, euphemistically called romusha (economic soldiers). Most of them were peasants from Javanese villages, but they were recruited from outlying areas as well. They were forced to work on roads, structures of military defence, etc. The hardships associated with these conscriptions were considerable, and by far the most of the romusha are believed to have succumbed during the war years (Ricklefs 1981, p. 193).

125 According to the latest available data, from 2001, the number of people on the Alor Islands was 168,000, meaning 59 persons per square kilometre (Alor dalam angka 2002, p. 16). It will be remembered that the numbers of Van Galen only encompass Alor Island, excluding Pantar. 
has taken place, especially in the areas of resistance, the districts Welai, Limbur and Mataru. The christianization has nevertheless taken off with renewed zeal after the liberation.

The religion of the pagans is animist. The belief in supernatural powers - good as well as evil - rules (ruled) the life of the Alorese. These supernatural powers were revered in the form of wooden images. They could also, however, take their abode in humans, animals, stones and other objects. The general name for such images, insofar as far as they all have the common form of a horned crocodile-like animal, is "naga". In the thesis "De sociale structuur van een Aloreesche bevolkinggroep" by Mej. Nicolspeyer ${ }^{126}$, the author mentions as models of some of the divinities revered in the nagas: the ulelai, the karibileni, the iawara, the fulik, the nera, and the timang.

1. The ulelai and the karibileni would be the spirits of the kinsfolk, of which the former, the ulelai, is the foremost and belongs to the kin property in the strictest sense, where inheriting is solely patrilineal. The karibileni can also be inherited in the female line. The quintessence of the ulelai cult consists of the bestowal of food, namely chicken and a mixture of rice and blood, to the ulelai. This feeding takes place at the following occasions:

a. When an image is erected. Through the erection the kin group expresses its intention to settle permanently at the place.

b. Once a year, when working on the gardens starts again.

c. When someone is sick and the seer, who acts as the doctor, comes to the conclusion that the reason to the sickness lies in the displeasure of the ulelai.

2. The iawara, also represented in the form of a naga, is called Katahala and is erected if someone suddenly falls ill or if something inauspicious comes in his way (for instance, meeting a snake).

3. The fulik, the spirit of the pinang ${ }^{127}$, to whom one must bring offerings when the young pinang is planted.

4. The nera, which was supposedly introduced only recently (the thesis of Mej. Nicolspeyer is only about a group of the mountain people of Limbur). This naga was supposedly erected after someone met a snake at the coast.

5. The timang. The spirit who endows some persons with supernatural capabilities, come to visit them in their sleep and brings them along on various roamings. Such persons have the right to erect a small perahu ${ }^{128}$ in front of their house, and in that form the timang is revered. (Otherwise I noted that these perahu were made for the spirits of the deceased in order to travel to the realm of the dead, which is situated at the other side of the sea).

126 Martha Margaretha Nicolspeyer, De sociale structuur van een Aloreesche bevolkinggroep. Rijswijk: Kramers 1940. "Mej." is an abbreviation of Mejuffrouw, a nowadays seldom used term for Miss.

127 The pinang or betel nut is a ubiquitous stimylant in this part of Indonesia. It is chewed together with sirih leaves and lime.

128 A boat, in particular a small craft. 
Also the belief in witches of both sexes, the so-called suanggi, occurs everywhere. Murders of suanggi are, however, rare. ${ }^{129}$ (On Pantar some ten suanggis were killed during the war on the instruction and pressure by a Japanese soldier called Anai).

\section{CHRISTIANITY}

The evangelization is in the hands of the Indian Church. ${ }^{130} \mathrm{~A}$ few Catholics occur in the mountain kampung Tombang above Kalabahi, where a guru of the Indian Church who converted to the Roman Catholic Church in Makassar, has some followers.

The pagan population of Alor and Pantar has to a large part converted to Christianity. Among the mountain people of Central Alor the success is the least. The mountain districts Welai and Limbur are now in the centre of attention for the mission. In order to make good the enormous reverse brought about by the Japanese rule, they are at hard work. It is unfortunate that the Indian preacher Mollema ${ }^{131}$ was recently evacuated to Holland, and that momentarily no successor is available.

At the moment there are 13 indigenous instructors (pendeta ${ }^{132}$ ), 56 guru agama $^{133}$, and 63 utusan injil. ${ }^{134}$ Before the war these numbers were, respectively, 16, 41 and 22 . The Indian preacher and the pendeta were salaried through the governmental treasure. As for the guru agama, these popular teachers often receive an addition from the evangelization funds, from which also the utusan injil are paid. The evangelization funds in the first place receive their money from the Christian community of Batavia. At the moment the costs for the entire evangelization work is preliminarily purveyed by the governmental treasure.

One should of course not expect that Christianity has already grown deep roots. However, the generally civilizing influence that originates from Christianity and above all from the popular schools is important. Proper dressing and washing (?) at public events, especially by the younger generation before they go to church on Sundays, can be regarded as a gain from a hygienic point of view. Christianity has had a debilitating influence on polygamy; nevertheless it still often occurs among chiefs and well-to-dos. The influence that Christianity has on the relation between Indonesians and Dutchmen is well known, which does not mean that Christianity would work in a debilitating way on a sound nationalism. ${ }^{135}$

Christianity has gained its greatest dissemination through the popular schools. The popular instruction is in the hands of the Indian Church. The teachers often act simultaneously as guru. In previous and especially in present times, the self-rulers ${ }^{136}$ have complained about the com-

129 By contrast, killings of suspected witches were relatively common on Timor.

130 The Indische Kerk was a Reformed Christian church organization that performed missionary activities in particular in the Moluccas (Gonggrijp 1934, p. 1550).

131 The missionary C.W. Mollema was active on the Alor islands in 1941-42, in other words just before the Japanese invasion (Rodemeier 2006, p. 83).

132 A pendeta is a Protestant clergyman or a Hindu or Buddhist priest, depending on the circumstances.

133 Religious teachers.

134 Messengers of the Gospel, evangelistic missionaries.

135 By "sound nationalism", Van Galen presumably means a modest type of nationalism that was tolerated within the Dutch-directed quasi-state Negara Indonesia Timur.

136 Zelfbestuurders, that is Dutch-appointed rajas. 
bination of teacher and guru. ${ }^{137}$ Since higher and higher demands are exacted on the teachers regarding the field of education, these complaints are also lodged by the inspection and by the Indian Church. The aim is then also established to delegate the religious duties to particular guru agama, and to limit the task of the teacher as guru agama, to the kampung where the school is situated.

For the primitive mountain areas of Central Alor, where the school can rather be considered a civilizing school, the combination of teacher and guru agama in my view even has certain advantages.

\section{ISLAM}

One encounters Islam in the coastal kampungs of the kapitan-ship Dulolong and the formost coastal kampungs of Pantar Island. Also Lerabaing, the old place of residence of the Raja of Kui, is entirely Islamic. The formost centres on Alor are Kalabahi (the kampungs Binongko and Wetabua), Dulolong, Alor Kecil and Alor Besar, Uma Pura on the island of that name, and the mountain kampung Topubang. On Pantar, in the first hand, the great kampung Blangmerang, Kayang on the west coast, Pandai or Dinanglain on the north coast, Nuhawala-Kolijahi and Bakalan on the east coast. The total number of Muslims can be estimated at about 14,300 souls.

Islam is introduced here in the first hand from the Solor Islands and Endeh (Lerabaing). ${ }^{138}$ Under the influence of former political associations such as Parsi ${ }^{139}$ and PSII ${ }^{140}$ and the more bona fide religious association Assirathal Mustaqiam, the religious way of life and the quest to expand and propagate Islam is evoked. However, until now they have had little success among the mountain people (an exception to this is the abovementioned mountain kampung Topubang). In the time of the mutiny of the military detachment in Kalabahi in March 1942, they tried to make proselytes through frightening people; to be a Christian was namely considered to be anti-Japanese and pro-Dutch. Over this a conflict soon ensued between the Christian mutineers and the Javanese militaries, which resulted in the abrogation of co-operation between the mutineers and the leaders of political associations, so that this action was put to an end.

In the last year of Japanese occupation the Persiapan (Siap - Serekat Islam Alor dan Pantar) ${ }^{141}$ was established via the encouragement of the Japanese. On its program was, apart from the advancement of issues of the Muhammedan population, the co-operation with the Japanese until the final victory. ${ }^{142}$ The formost figures of this association were Beleng Maleng, former Kapitan of Dulolong (sentenced in 1940 due to obfuscation and falsity in writings), the Imam

137 Teacher, in the sense of religious teacher.

138 Ternate, the island sultanate in the northern Moluccas, was also an important source of Islamic influence. Traditions pertaining to Ternatean contacts with the Alor Islands are discussed in Rodemeier 2006, pp. 217-20.

139 Partai Sosialis Indonesia, a party established in 1945. It formally joined another socialist party later in the same year, but kept its own profile.

140 Partai Sarekat Islam Indonesia, a party established in 1923.

141 The acronyme is also a pun, since persiapan means preparation.

142 In spite of their severe rule in 1942-45, the Japanese occupants took care to foster anti-Dutch, nationalist forces in Indonesia, with consequences for the revolutionary movement after 1945. 
of Dulolong Mohammad Idris, father-in-law of the Raja Muda, the Raja Muda, and Soleman Abdullah, trader in Kalabahi.

The relation between the Muhammedan coastal population and the mountain people has for a long time been less good. ${ }^{143}$ The tense relation is sharpened rather than lessened through the conversion of the greatest part of the mountain people to Christianity, and the actions by the leaders of political associations before and during the occupation. However, one need not fear eruptions, as long as the mountain people are convinced of the neutral stance of the government. Also, the always very moderate position of the Rajas of Alor and Kui has certainly not been without good results.

\section{References}

Alor dalam angka. 2002. Alor dalam angka 2001. Kalabahi: BPS Kabupaten Alor.

Andaya, Leonard Y. 1993. The world of Maluku: Eastern Indonesia in the early modern period. Honolulu: University of Hawaii Press.

Andaya, Leonard Y. 1995. The Bugis-Makassar diasporas. Journal of the Malay Bransch of the Royal Asiatic Society 68(1): 119-39.

ANRI Timor, various years. Access number K. 43. Arsip Nasional Republik Indonesia, Jakarta. Arago, Jacques. 1823. Narrative of a voyage round the world. London.

Arago, Jacques. 1844. Minnen af en blind. Stockholm: L. J. Hjerta.

Barnes, Robert H. 1995. 'Lamakera, Solor: Ethnohistory of a Muslim whaling village in eastern Indonesia.' Anthropos 90: 497-509.

Bell, Alexander, et al., 2009. Sistem pemerintahan tradisional di Kabupaten Alor. Kupang:

Dinas Kebudayaan dan Pariwisata.

Bik, J.Th., 1821. Eenige aanteekeningen van mijne reis met de Directeur tot de zaken van landbouw, kunsten en wetenschappen naar Timor en de Moluksche eilanden, H 601, KITLV Archive, Leiden (unpublished manuscript).

Boli Lajar, Leo. 2007. Sejarah terjadinya Kerajaan Labala. Kalikasa, Lembata (unpublished manuscript).

Boxer, C.R. 1947. The Topasses of Timor. Amsterdam: Koninklijke Vereeniging Indisch Instituut. Castro, Affonso de. 1867. As possessões Portuguezas na Oceania. Lisboa: Imprensa Nacional.

Coolhaas, W.Ph. (ed.). 1979. Generale missiven van Gouverneurs-Generaal en Raden aan Heren XVII der Verenigde Oost-Indische Compagnie, Vol. VII: 1713-1725. Den Haag: M. Nijhoff.

Dijk, L.J. van. 1925, 1934. 'De zelfbesturende landschappen in de Residentie Timor en Onderhoorigheden.' Indische Gids.

Du Bois, Cora. 1944. The people of Alor: A social-psychological study of an East Indian island. Minneapolis: The University of Minnesota Press.

Ecoma Verstege, C.M.G.A.M. van, 1878, Memorie van Overgave. MMK 337. Nationaal Archief, The Hague (unpublished report).

Francis, Emanuel. 1832. Verslag van den Kommisaris voor Timor, H 548, KITLV Archive, Leiden (unpublished manuscript).

143 This may have changed for the better after the winning of independence. The Alor Islands have in fact been free from serious inter-religious conflicts in modern time, in contrast with several other Indonesian regions (Gomang 2006). 
Gomang, Syarifuddin R. 1993. The People of Alor and their alliances in eastern Indonesia: A study of political sociology. MA Thesis, University of Wollongong.

Gomang, Syarifuddin R. 2006. 'Muslim and Christian alliances: 'Familial relationships' between inland and coastal peoples of the Belagar community in eastern Indonesia.' Bijdragen tot de Taal-, Land-en Volkenkunde 162-4: 468-89.

Gonggrijp, G.F.E., 1934, Geïllustreerde encyclopaedie van Nederlandsch-Indië. Amsterdam \& Soerabaja: Graauw's.

Hägerdal, Hans, 2010, 'Cannibals and pedlars: Economic opportunities and political alliance in Alor, 1600-1850.' Indonesia and the Malay World 38, pp. 217-46.

Kontrak Perjanjian, 2007, Kontrak Perjanjian Wilayah Perbatasan Republik Indonesia, Jilid II: Wilayah Laut Andaman, Selat Malaka, dan Laut Sawu, Timor. Jakarta: ANRI.

Lemoine, Annie. 1969. 'Histoires de Pantar.' L'Homme 9: 5-23.

LeRoux, C.C.F.M. 1929. 'De Elcano’s tocht door den Timor-archipel met Magelhães' schip ”Victoria".' In Feestbundel uitgegeven van het Koninklijk Bataviaasch Genootschap voor kunsten en wetenschappen, Vol. 2. Weltevreden: Kolff \& Co. Pp. 1-100.

Lijnden, D.W.C. Baron van. 1851. 'Bijdrage tot de kennis van Solor, Allor, Rotti, Savoe en omliggende eilanden, getrokken uit een verslag van de Residentie Timor.' Natuurkundig Tijdschrift voor Nederlandsch-Indië 2: 317-36, 388-414.

Mailrapporten, various years, Nationaal Archief, The Hague.

Monteiro, Jozé Maria de Souza, 1850, Diccionario Geographico das Provincias e Possesões Portuguezas no Ultramar. Lisboa: Typographia Lisbonense.

Pélissier, René. 1996. Timor en guerre: Le crocodile et les Portugais (1847-1913). Orgeval.

Ricklefs, M.C., 1981, A History of Modern Indonesia. Houndmills: Macmillan.

Rodemeier, Susanne. 2006. Tutu kadire in Pandai - Munaseli. Erzählen und Erinnern auf der vergessenen Insel Pantar (Ostindonesien). Berlin: Lit Verlag.

Roever, Arend de. 2002. De jacht op sandelhout: De VOC en de tweedeling van Timor in de zeventiende eeuw. Zutphen: Walburg Pers.

Sartono Kartodirdjo et al. (ed.), 1973, Ikhtisar Keadaan Politik Hindia-Belanda Tahun 1839-1848. Jakarta: ANRI.

Sogo, M.U., n.d., Kisah singkat asal-usul Bapak Tahir Noke Salama dan terbentuknya kerajaan Belagar (unpublished manuscript). 